
\title{
AGROTEKNIKA
}

\section{Rancang Bangun dan Analisis Mesin Pengupas Kulit Kacang Tanah Tipe Silinder Horizontal}

\section{Design and Analysis of Horizontal Cylinder-Type Peanut Skin Peeling Machine}

\author{
Muhammad Anwar*, Aldi Pratama, Rio Andria Saputra, Nur Kholilah, Naufal Alfayyadh, \\ Muhammad Riza Nurtam, Indra Laksmana
}

Program Studi Teknologi Mekanisasi Pertanian, Politeknik Pertanian Negeri Payakumbuh, Indonesia

\author{
*Penulis Korespondesi \\ Email: mhd.anwar060399@gmail.com
}

\begin{abstract}
Abstrak. Proses pemisahan biji dan kulit kacang tanah dapat dilakukan secara tradisional atau menggunakan mesin. Pengupasan kacang tanah secara tradisional dilakukan dengan menggunakan tangan (tanpa alat bantu) atau tongkat. Pengupasan kacang secara tradisional ini tanah dengan menggunakan tangan membutuhkan banyak tenaga dan waktu walaupun hasil pengupasan sangat bagus. Sedangkan pengupasan kacang tanah dengan menggunakan tongkat membuat kualitas kacang tanah hasil kupasan buruk dengan kapasitas kupasan kacang tanah yang juga kecil. Penelitian ini bertujuan membuat mesin pengupas kulit kacang tanah untuk skala industri rumah tangga dan melakukan analisis kinerja serta analisis ekonomi. Metode penelitian dimulai dari identifikasi masalah, penyempurnaan ide rancangan, dilakukan pembuatan alat, uji fungsional, uji kinerja dan terakhir dilakukan analisis ekonomi. Hasil uji kinerja mesin pengupas kulit kacang tanah tipe silinder horizontal diperoleh kapasitas alat 15,22 kg/jam, persentase kacang tidak terkupas 50\%, rendemen 33,5\%, dan persentase kerusakan hasil 2,15\%. Hasil analisis ekonomi teknik diperoleh biaya tetap Rp. 1.654.853,36/tahun, biaya tidak tetap Rp. $27.648,13 / \mathrm{jam}$, biaya pokok Rp. 1.879,48/kg, dan BEP sebanyak 1.732,03 kg/tahun. Mesin ini sangat cocok untuk skala industri rumah tangga karena mempunyai kapasitas 15,22 kg/jam dengan biaya listrik yang kecil sebesar Rp. 272,91/jam.
\end{abstract}

Kata kunci: kacang tanah, mesin pengupas, uji kinerja, analisis ekonomi

Abstract. The process of separating the seeds and peanut shells can be done traditionally or using a machine. The peeling of peanuts is traditionally done using hands (without tools) or sticks. This traditional peeling of the ground by hand takes a lot of effort and time, although the results of the peeling are very good. Meanwhile, peeling peanuts using a stick makes the peeled peanuts poor quality with a small peel capacity. This study aims to make a peanut shell peeler for a home industry scale and perform performance analysis and economic analysis. The research method starts with problem identification, perfecting the design idea, then making tools, functional testing, performance testing, and finally conducting economic analysis. The results of the horizontal cylinder type peanut shelling machine performance test showed that the tool capacity was 15.22 $\mathrm{kg} / \mathrm{hour}$, the percentage of unpeeled peanuts was $50 \%$, the yield was $33.5 \%$, and the percentage of damage to the yield was $2.15 \%$. The results of the technical-economic analysis obtained a fixed cost of Rp. 1,654,853.36 / year, variable costs Rp. 27,648.13 / hour, the basic cost of Rp. 1,879.48 
$/ \mathrm{kg}$, and BEP $1,732.03 \mathrm{~kg} /$ year. This machine is very suitable for home industry scale because it has a capacity of $15.22 \mathrm{~kg} / \mathrm{hour}$ with a small electricity cost of Rp. 272.91 / hour.

Keywords: peanut, peeler, performance test, economic analysis

\section{Pendahuluan}

Kacang tanah adalah salah satu komoditas pertanian yang menjadi sumber protein dalam pola pangan penduduk Indonesia dan bernilai ekonomi cukup tinggi. Biji kacang tanah dapat diolah menjadi bahan makanan seperti kacang goreng, bumbu, industri pangan dan lain-lain dengan dilakukan beberapa tahap pengolahan (Najiyanti \& Danarti, 1999).

Untuk mendukung peningkatan produksi kacang tanah, maka perlu perlakuan dalam pengolahan pascapanen kacang tanah, salah satunya adalah pada proses pengupasan kulit kacang (Zuhdi, 2015). Proses pemisahan biji dan kulit kacang sebelumnya dilakukan secara tradisional dengan menggunakan tangan (tanpa alat bantu) dan tongkat. Pengupasan kacang tanah dengan cara dipukul dan diinjak menngunakan tongkat membuat banyak biji yang pecah, sehingga menurunkan kualitas hasil pengupasan (Haryoto, 1995).

Mesin pengupas kulit kacang tanah telah dimodifikasi oleh Tahapali et al. (2019) kapasitas $10,28 \mathrm{~kg} / \mathrm{jam}$. Salahudin et al. (2018) telah melakukan uji kinerja mesin pengupas kulit kacang tanah dengan tipe piramida berputar. Pada saat kecepatan putar $93 \mathrm{rpm}$ diperoleh persentase pengupasan tertinggi dengan nilai $82,44 \%$. Mesin ini memiliki kapasitas tertinggi 27,48 kg/jam pada kecepatan putar ruji $116 \mathrm{rpm}$. Salahudin and Widodo (2018) telah membuat mesin pengupas kulit kacang tanah dengan nilai persentase kacang tanah terkupas secara baik sebesar $80,96 \%$ dengan variasi jarak ruji $15 \mathrm{~mm}$. Sedangkan pada variasi jarak ruji $20 \mathrm{~mm}$ diperoleh kapasitas tertinggi sebesar 28,48 kg/jam. Berdasarkan hal tersebut penelitian ini bertujuan membuat mesin pengupas kulit kacang tanah untuk skala industri rumah tangga. Penelitian ini juga melaskanakan analisis kinerja dan analisis ekonomi pada mesin pengupas kulit kacang tanah.

\section{Bahan dan Metode}

Bahan-bahan yang diperlukan dalam pembuatan mesin pengupas kulit kacang tanah tipe silinder horizontal terdapat dalam Tabel 1.

\section{Metode Penelitian}

Metode penelitian dimulai dari identifikasi masalah, penyempurnaan ide rancangan, selanjutnya dilakukan pembuatan alat, uji fungsional, uji kinerja, dan terakhir dilakukan analisis ekonomi. Diagram alir metode penelitian seperti pada Gambar 1. 
Agroteknika 3 (2): 109-119 (2020)

Tabel 1. Bahan pembuatan mesin pengupas kulit kacang tanah tipe silinder horizontal

\begin{tabular}{rlll}
\hline No & \multicolumn{1}{c}{ Bahan } & \multicolumn{1}{c}{ Spesifikasi } & \multicolumn{1}{c}{ Jumlah } \\
\hline 1 & Motor listrik & $0,25 \mathrm{hp}$ & 1 unit \\
2 & Besi plat & $1.2 \mathrm{~mm}$ & $1 / 2$ lembar \\
3 & Besi as & $20 \mathrm{~mm}$ & $1 \mathrm{~m}$ \\
4 & Besi siku & $3 \times 3$ & 2 batang \\
5 & Bearing ucp & P204 & 2 buah \\
6 & Elektroda & Rb2,6 & $1 \mathrm{~kg}$ \\
7 & Baut dan mur & Diameter $12 \mathrm{~mm}$ & 4 buah \\
8 & Baut dan mur & Diameter $10 \mathrm{~mm}$ & 8 buah \\
9 & Pulley & 1 inch & 1 buah \\
10 & Pulley & 12 inch & 1 buah \\
11 & V-belt & A63 & 1 buah \\
12 & Besi pipa & $30 x 12 \mathrm{~cm}$ & 1 buah \\
13 & Besi beton & Diameter $10 \mathrm{~mm}$ & 2 meter \\
14 & Mata gerinda & A30PBF & 2 Buah \\
15 & Seng plat & $0,25 \mathrm{~mm}$ & 1 lembar \\
16 & Per tekan & $5 \mathrm{~cm}$ & 2 buah \\
\hline
\end{tabular}

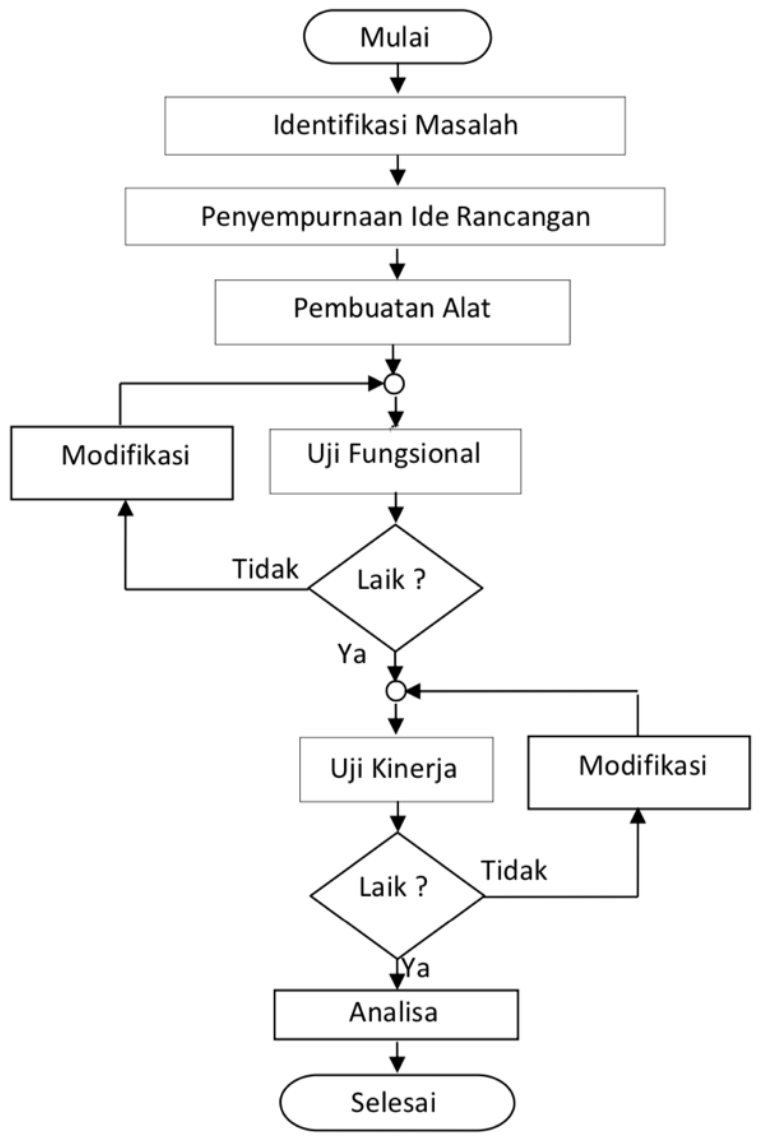

Gambar 1. Diagram alir metode penelitian

\section{Rancangan Alat}

Rancangan fungsional serta struktural menerangkan tentang guna serta dimensi dari komponen- komponen mesin pengupas kulit kacang tanah tipe silinder horizontal. Rancangan fungsional dan struktural terdiri dari: 
Kerangka

Kerangka berguna untuk penompang seluruh kedudukan komponen. Kerangka terbuat dari besi siku 3 x 3 tebal $3 \mathrm{~mm}$, panjang $90 \mathrm{~cm}$, lebar $41 \mathrm{~cm}$, dan tinggi $70 \mathrm{~cm}$. Rancangan rangka seperti Gambar 2.

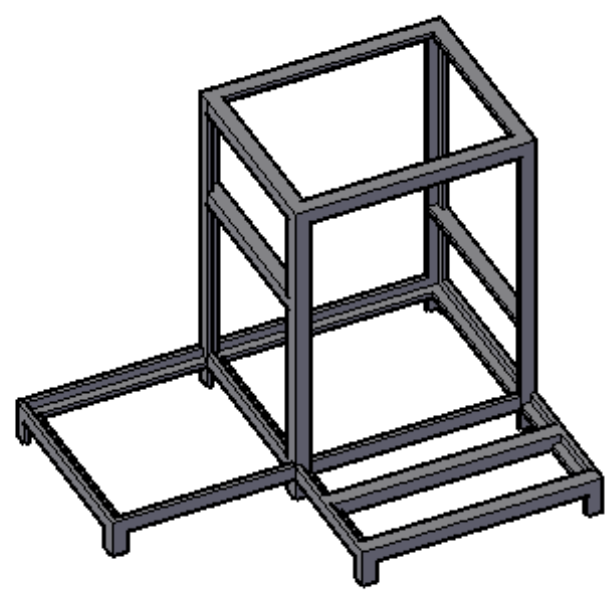

Gambar 2. Kerangka

Motor listrik

Motor listrik sebagai sumber penggerak dari mesin pengupas kulit kacang tanah tipe silinder horizontal. Motor listrik yang digunakan mempunyai daya sebesar 0,25 Hp dan kecepatan putar 1.480 rpm. Motor listrik seperti Gambar 3.

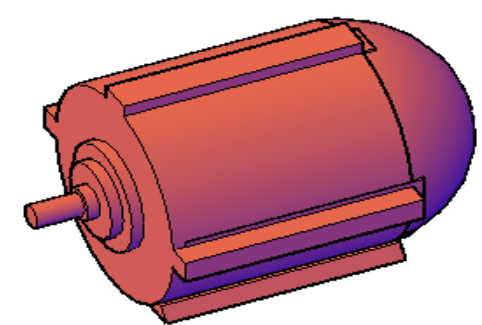

Gambar 3. Motor listrik

Mata pengupas

Mata pengupas berfungsi sebagai pengupas kulit kacang tanah untuk memisahkan biji dari kulit kacang. Mata pengupas yang digunakan adalah besi pipa yang berbentuk silinder dengan diameter $12 \mathrm{~cm}$, panjang $30 \mathrm{~cm}$ dan terdapat besi beton berdiameter $10 \mathrm{~mm}$, dan panjang $28 \mathrm{~cm}$ sebagai mata pengupas di sekeliling besi pipa. Rancangan mata pengupas seperti Gambar 4.

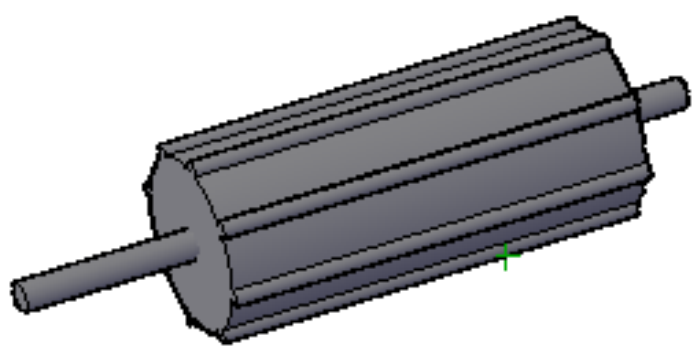

Gambar 4. Mata pengupas 
Rumah mata pengupas

Rumah mata pengupas berfungsi sebagai penutup mata pisau supaya pada saat pengupasan biji kacang tidak berterbangan keluar. Rumah mata pengupas terbuat dari besi plat tebal $1 \mathrm{~mm}$ dengan ukuran panjang $32 \mathrm{~cm}$, lebar $33 \mathrm{~cm}$ dan tinggi $3 \mathrm{~cm}$. Rancangan rumah mata pengupas seperti Gambar 5.

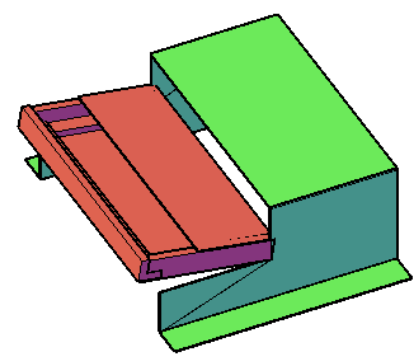

Gambar 5. Rumah mata pengupas

\section{Hopper}

Hopper berfungsi sebagai wadah pemasukan kacang tanah yang akan dikupas. Hopper terbuat dari besi plat tebal $1 \mathrm{~mm}$ dengan ukuran tinggi $20 \mathrm{~cm}$, lebar $32 \mathrm{~cm}$ dan panjang $21 \mathrm{~cm}$. Rancangan hopper seperti Gambar 6.

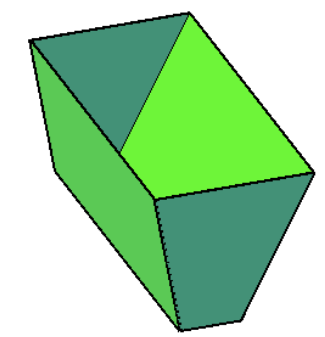

Gambar 6. Hopper

Saringan

Saringan berfungsi sebagai penyortir biji untuk dapat memisahkan biji dan kulit kacang tanah. Saringan terbuat dari seng plat tebal $0,25 \mathrm{~mm}$ panjang $62 \mathrm{~cm}$ dan lebar $32 \mathrm{~cm}$ yang pada seluruh permukaannya dibuat lubang dengan diameter $13 \mathrm{~mm}$. Rancangan saringan seperti Gambar 7.

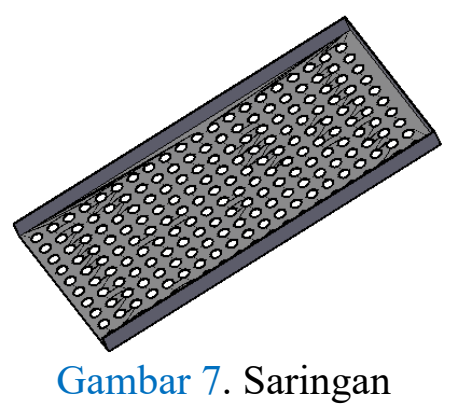

Outlet

Outlet berfungsi sebagai saluran pengeluaran. Outlet terbuat dari seng plat dengan ukuran panjang $62 \mathrm{~cm}$ dan lebar $32 \mathrm{~cm}$. Rancangan outlet seperti Gambar 8. 


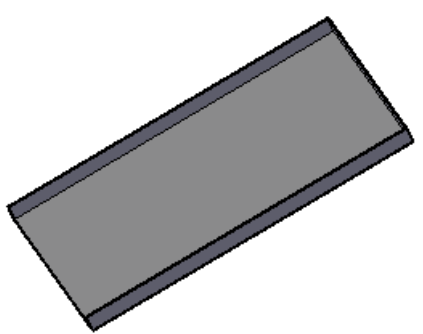

Gambar 8. Outlet

Pulley dan v-belt

Pulley dan $v$-belt berguna untuk sistem transmisi tenaga ke poros penggerak dari motor listrik. $V$-Belt yang digunakan pada mesin pengupas kulit kacang tanah yaitu tipe A63 dengan ukuran pulley kecil berdiameter 1 inch pada motor listrik dan pulley besar berdiameter 12 inch terletak pada poros silinder. Rancangan pulley dan v-belt seperti Gambar 9.

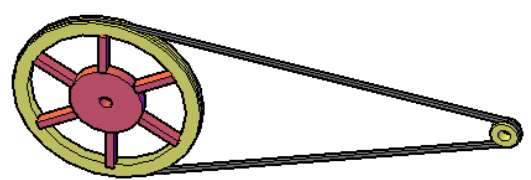

Gambar 9. Pulley dan v-belt

Rancangan keseluruhan mesin pengupas kulit kacang tanah dengan tipe silinder horizontal seperti Gambar 10.

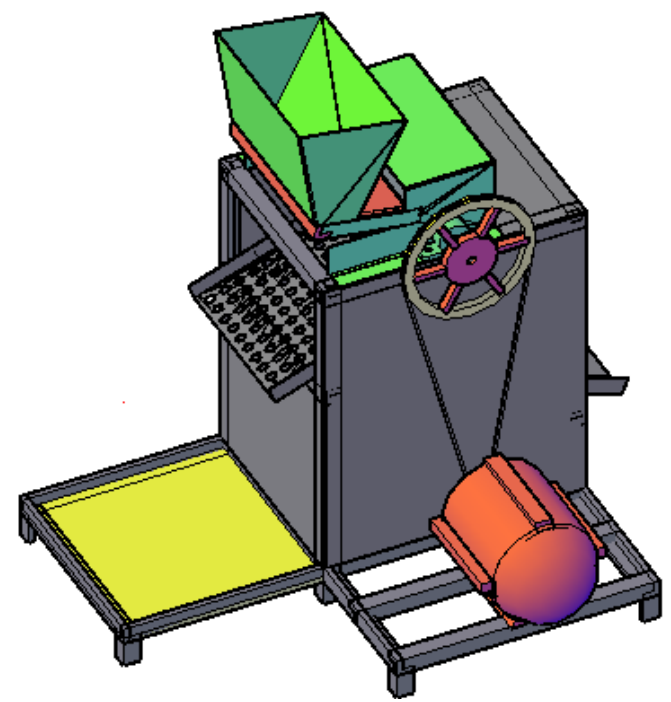

Gambar 10. Mesin pengupas kulit kacang tanah dengan tipe silinder horizontal

\section{Prinsip Kerja}

Prinsip kerja mesin pengupas kulit kacang tanah dengan tipe silinder horizontal yaitu tenaga motor listrik yang dihubungkan pada pulley-v belt sebagai mekanisme transmisi sehingga menggerakkan poros untuk berputar. Besi beton yang terdapat disekeliling silinder sebagai mata pisau akan berputar ke arah mata pisau yang diam sehingga akan mengeluarkan biji dari kulit kacang tanah. Kulit kacang dan biji kacang akan dipisah menggunakan saringan yang terdapat pada bagian bawah mata pengupas dan keluar di outlet. 


\section{Hasil dan Pembahasan}

Spesifikasi mesin pengupas kulit kacang tanah tipe silinder horizontal adalah:

$\begin{array}{ll}\text { Tinggi alat } & : 90 \mathrm{~cm} \\ \text { Lebar } & : 41 \mathrm{~cm} \\ \text { Panjang } & : 90 \mathrm{~cm} \\ \text { Panjang silinder } & : 30 \mathrm{~cm} \\ \text { Diameter silinder } & : 12 \mathrm{~cm} \\ \text { Panjang mata pengupas } & : 28 \mathrm{~cm} \\ \text { Diameter mata pengupas } & : 10 \mathrm{~mm} \\ \text { Panjang saringan } & : 62 \mathrm{~cm} \\ \text { Lebar saringan } & : 32 \mathrm{~cm} \\ \text { Diameter saringan } & : 13 \mathrm{~mm} \\ \text { Diameter pulley atas } & : 12 \mathrm{inch} \\ \text { Diameter pulley bawah } & : 1 \text { inch } \\ \text { Daya motor } & : 0,25 \mathrm{Hp}\end{array}$

Mesin pengupas kulit kacang tanah dengan tipe silinder horizontal seperti Gambar 11.

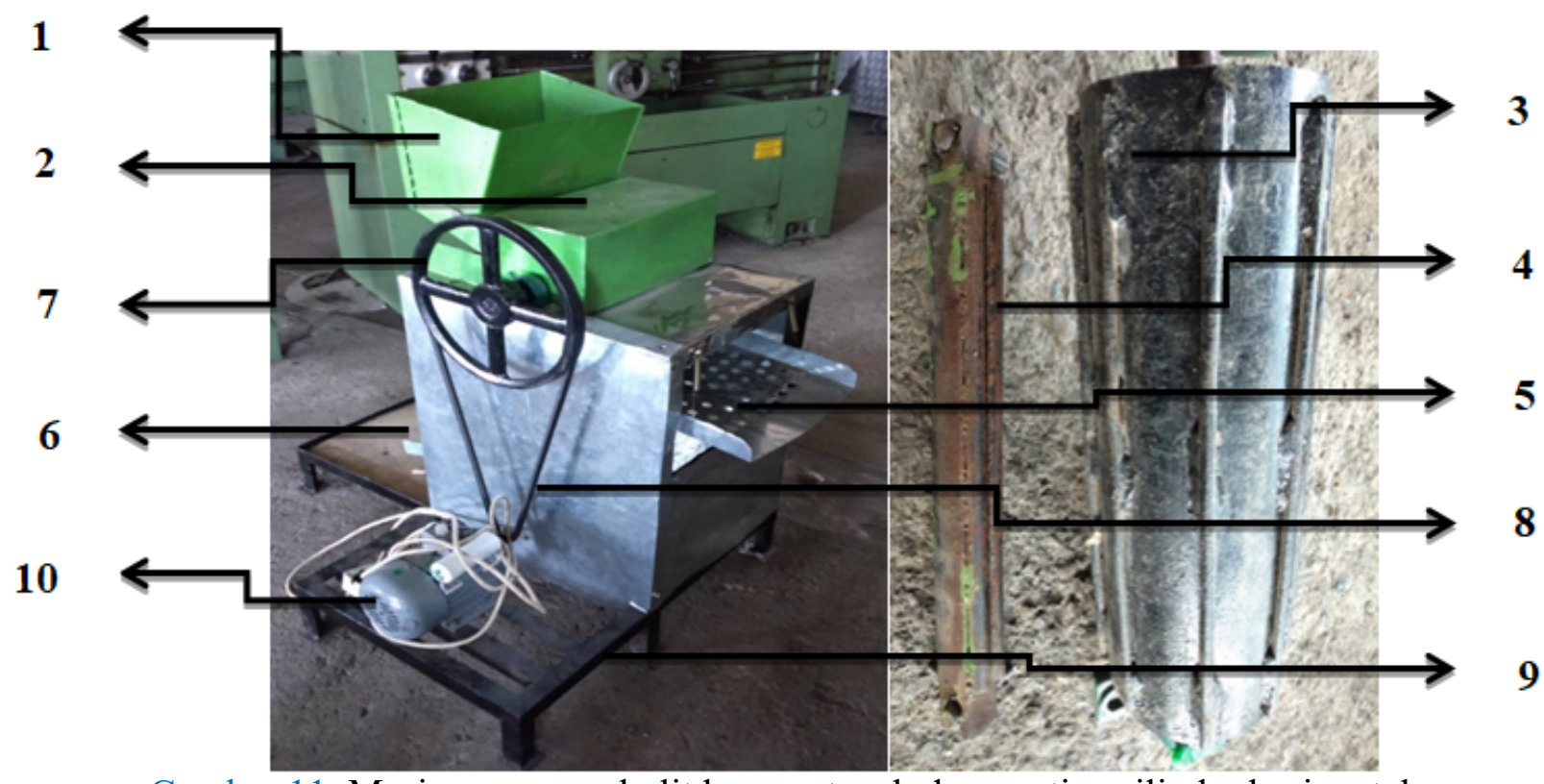

Gambar 11. Mesin pengupas kulit kacang tanah dengan tipe silinder horizontal

Keterangan:
1. Hopper
6. Pengeluaran outlet
2. Rumah mata pengupas
7. Pulley
3. Mata pengupas berputar
8. V-belt
4. Mata pengupas diam
9. Kerangka
5. Saringan
10. Motor listrik 


\section{Uji Kinerja}

Uji kinerja yang dilakukan pada mesin pengupas kulit kacang tanah dengan tipe silinder horizontal adalah sebanyak 3 kali pengujian. Berat bahan baku di setiap pengujian sebanyak $2 \mathrm{~kg}$, dan kadar air pada kacang tanah yaitu 36\%. Putaran pada mata pengupas sebesar $123 \mathrm{rpm}$. Parameter uji yang dilakukan yaitu kapasitas alat, rendemen, persentase kacang tidak terkupas, dan persentase kerusakan hasil. Data hasil uji kinerja pada mesin pengupas kulit kacang tanah dengan tipe silinder horizontal seperti Tabel 2.

Tabel 2. Data hasil uji kinerja

\begin{tabular}{|c|c|c|c|c|c|c|c|}
\hline \multirow[b]{2}{*}{ Pengujian } & \multirow[b]{2}{*}{$\begin{array}{l}\text { Berat } \\
\text { kacang } \\
(\mathrm{kg})\end{array}$} & \multirow[b]{2}{*}{$\begin{array}{c}\text { Waktu } \\
\text { pengupasan } \\
\text { (jam) }\end{array}$} & \multirow[b]{2}{*}{$\begin{array}{c}\text { Kacang tidak } \\
\text { Terkupas } \\
(\mathrm{kg})\end{array}$} & \multicolumn{4}{|c|}{ Hasil Pengupasan } \\
\hline & & & & $\begin{array}{c}\text { Biji } \\
\text { rusak } \\
(\mathrm{kg})\end{array}$ & $\begin{array}{c}\text { Biji } \\
\text { bagus } \\
(\mathrm{kg})\end{array}$ & $\begin{array}{c}\text { Kulit } \\
\text { terkupas } \\
(\mathrm{kg})\end{array}$ & $\begin{array}{c}\text { Biji } \\
\text { terkupas } \\
(\mathrm{kg})\end{array}$ \\
\hline 1 & 2 & 0,018 & 1,4 & 0,05 & 0,35 & 0,2 & 0,4 \\
\hline 2 & 2 & 0,057 & 0,8 & 0,01 & 0,79 & 0,4 & 0,8 \\
\hline 3 & 2 & 0,058 & 0,8 & 0,07 & 0,73 & 0,4 & 0,8 \\
\hline Jumlah & 6 & 0,133 & 3 & 0,13 & 1,87 & 1 & 2 \\
\hline Rata-rata & 2 & 0,044 & 1 & 0,043 & 0,62 & 0,33 & 0,67 \\
\hline
\end{tabular}

\section{Kapasitas mesin}

Kapasitas mesin merupakan kemampuan mesin untuk memperoleh hasil pengupasan dari kacang tanah dalam satuan per jam. Perhitungan kapasitas mesin ditentukan dengan rumus, hasil pengupasan di bagi waktu pengupasan.

Kapasitas alat $=\frac{0,67 \mathrm{~kg}}{0,044 \mathrm{jam}}=15,22 \mathrm{~kg} / \mathrm{jam}$

Kapasitas mesin pengupas kulit kacang tanah tipe silinder horizontal yang diperoleh adalah 15,22 kg/jam. Kapasitas pada mesin ini lebih kecil dari mesin yang dibuat oleh Salahudin et al. (2018) dan Salahudin and Widodo (2018) tetapi lebih besar dari Tahapali et al. (2019).

\section{Persentase kacang tidak terkupas}

Persentase kacang tidak terkupas yaitu perbandingan kacang yang tidak terkupas pada saat pengoperasian alat dalam bentuk persen (\%). Persentase kacang tidak terkupas dihitung dengan rumus :

Kacang tidak terkupas $=\frac{1 \mathrm{~kg}}{2 \mathrm{~kg}} \times 100 \%=50 \%$

Persentase kacang tidak terkupas pada mesin ini lebih besar dari mesin yang dibuat oleh Salahudin et al. (2018); Salahudin and Widodo (2018) ; Tahapali et al. (2019). Hal ini disebabkan karena mata pengupas 2 yang tidak berputar cukup kuat untuk mengupas semua jenis ukuran kacang tanah, sehingga mesin pengupas kacang tanah ini tidak dapat bekerja dengan sempurna. 


\section{Rendemen}

Rendemen adalah jumlah hasil dari pengupasan dan perbandingan jumlah kuantitas hasil pengupasan dalam persen (\%). Untuk mencari rendemen dari mesin pengupas kacang tanah tipe silinder horizontal dengan rumus:

Rendemen $=\frac{0,67}{2 \mathrm{~kg}} \times 100 \%=33,5 \%$

Hal ini disebabkan karena per tekan pada mata pisau 2 yang tidak berputar kurang kuat untuk mengupas semua ukuran kacang tanah dan saringan yang terbuat dari seng plat tanpa per gantung untuk pengayakan penyortiran biji, sehingga mesin pengupas kacang tanah tipe silinder horizontal ini tidak dapat bekerja dengan sempurna.

\section{Persentase kerusakan hasil}

Persentase kerusakan hasil adalah hasil yang rusak pada biji kacang tanah yang diperoleh oleh mesin pada pengupasan dalam bentuk persen (\%). Persentase kerusakan hasil dihitung dengan rumus:

Biji rusak $=\frac{0,043 \mathrm{~kg}}{2 \mathrm{~kg}} \times 100 \%=2,15 \%$

Persentase kerusakan hasil pada mesin pengupas kulit kacang tanah tipe silinder horizontal adalah $2,15 \%$.

\section{Analisis Ekonomi}

Penelitian ini melakukan analisis ekonomi berdasarkan Kodoatie (2005) yang telah digunakan pada beberapa penelitian, yaitu: Novita et al. (2019); Adam et al. (2020); Womsiwor et al. (2018). Analisis biaya yang dilakukan terdiri dari biaya tetap (fixed cost), biaya tidak tetap (variable cost), Break event point (BEP) dan biaya pokok (Irwan \& Novita, 2016).

$\begin{array}{ll}\text { Harga jual alat }(\mathrm{P}) & =\mathrm{Rp} .6 .566 .880 \\ \text { Umur ekonomis }(\mathrm{N}) & =5 \text { tahun } \\ \text { Harga akhir }(\mathrm{S}) & =10 \% \mathrm{x} \mathrm{P} \\ \text { Tingkat suku bunga }(\mathrm{i}) & =12 \% / \text { tahun } \\ \text { Jam kerja/tahun(X) } & =1.728 \mathrm{jam} / \text { tahun } \\ \text { Jam kerja/hari } & =6 \mathrm{jam} \\ \text { Upah operator } & =80.000 / \mathrm{hari} \\ \text { Jumlah operator } & =2 \mathrm{orang} \\ \text { Upah pengupasan manual }(\mathrm{R}) & =\mathrm{Rp} .2 .772 / \mathrm{kg} \\ \text { Kapasitas alat }(\mathrm{C}) & =15,22 \mathrm{~kg} / \mathrm{jam}\end{array}$

\section{Biaya tetap}

Komponen untuk biaya tetap pada mesin pengupas kulit kacang tanah yaitu biaya penyusutan dan bunga modal. 
Biaya penyusutan

$(D)=\frac{(P-S)}{n}$

$\mathrm{S} \quad=10 \% \times \mathrm{P}=10 \% \times \mathrm{Rp} .6 .566 .880=\mathrm{Rp} .656 .688$

$D=\frac{\text { Rp. } 6.566 .880-\text { Rp.656.688 }}{5 \text { tahun }}=$ Rp. 1.182 .038

Bunga modal

$(I)=\frac{i(P)(N+I)}{2 n}=\frac{12 \%(\mathrm{Rp} .6 .566 .880)(5+1)}{2 * 5 \text { tahun }}=\mathrm{Rp} .472 .815,36 / \mathrm{th}$

Biaya tetap = biaya penyusutan + bunga modal

$=$ Rp. 1.182.038/th + Rp. $472.815,36 /$ th $=$ Rp. $1.654 .853,36 /$ th

\section{Biaya tidak tetap}

Biaya tidak tetap untuk mesin pengupas kulit kacang tanah terdiri dari biaya upah operator, biaya perawatan dan biaya listrik.

Upah operator

Upah operator $=($ upah $(\mathrm{Rp})$ perhari $\mathrm{x}$ jumlah operator $) /($ jam kerja perhari $)$

$$
=\frac{\text { Rp.80.000 } \times 2 \text { orang }}{6 \text { jam } / \text { hari }}=\text { Rp. 26.666/jam }
$$

Biaya perawatan

Biaya perawatan $=\frac{(1,2 \%) \mathrm{X}(\mathrm{P}-\mathrm{S})}{100 \mathrm{jam}}=\frac{1,2 \% \mathrm{X}(\text { Rp. 6.566.880-Rp. 656.688) }}{100 \mathrm{jam}}=\mathrm{Rp} .709,22 / \mathrm{jam}$

Biaya listrik

Biaya listrik = daya motor* harga listrik

$$
\begin{aligned}
& =186,4 \text { watt } * \text { Rp. } 1 \cdot 467,28 / \mathrm{kWh} \\
& =0,186 \mathrm{kWh} * \text { Rp. } 1 \cdot 467,28 / \mathrm{kWh}=\text { Rp. } 272,91 / \mathrm{jam}
\end{aligned}
$$

biaya tidak tetap $=$ upah operator + biaya perawatan + biaya daya listrik

$$
=\text { Rp.26.666/jam }+ \text { Rp. 709,22/jam +Rp. 272,91/jam =Rp. 27.648,13/jam }
$$

\section{Biaya pokok}

Biaya pokok adalah biaya yang dibutuhkan oleh mesin pada saat operasional untuk hasil produksi.

$\mathrm{BP}=\frac{\frac{\mathrm{BT}}{\mathrm{X}}+\mathrm{BTT}}{\mathrm{C}}$

$\mathrm{BP}=\frac{\frac{\mathrm{Rp} \cdot 1.654 .853,36 / \mathrm{th}}{1.728 \mathrm{jam} / \mathrm{th}}+\mathrm{Rp} \cdot 27.648,13 / \mathrm{jam}}{15,22 \mathrm{~kg} / \mathrm{jam}}=\mathrm{Rp} .1 .879,48 / \mathrm{kg}$

\section{Break event point (BEP)}

$B E P=\frac{\mathrm{BT}}{\mathrm{R}-\frac{\mathrm{BTT}}{\mathrm{C}}}=\frac{R p \cdot 1 \cdot 654.853,36 / \text { tahun }}{\mathrm{Rp} \cdot 2.772 / \mathrm{kg}-\left(\frac{(\mathrm{Rp} .27 .648,13 / \mathrm{jam})}{15,22 \mathrm{~kg} / \mathrm{jam}}\right.}=1.732,03 \mathrm{~kg} / \mathrm{tahun}$ 


\section{Kesimpulan}

Mesin pengupas kulit kacang tanah tipe silinder horizontal menggunakan motor listrik sebagai sumber penggerak komponen lainnya dengan daya $0,25 \mathrm{hp}$ dan kecepatan putar $1.480 \mathrm{rpm}$ yang diubah menjadi $123 \mathrm{rpm}$ melalui perbandingan pulley $1: 12$. Hasil uji kinerja pada mesin pengupas kulit kacang tanah tipe silinder horizontal diperoleh kapasitas mesin 15,22 kg/jam, rendemen sebanyak 33,5\%, persentase kacang terkupas sebanyak 50\%, dan persentase kerusakan hasil sebanyak 2,15\%. Dari hasil analisis ekonomi diperoleh biaya tetap senilai Rp. 1.654.853,36/tahun, biaya tidak tetap senilai Rp. 27.648,13/jam, biaya pokok senilai Rp. 1.879,48/jam, dan BEP sebanyak 1.732,03/kg. Mesin ini cocok untuk skala industri rumah tangga karena mempunyai kapasitas 15,22 kg/jam dengan biaya listrik yang kecil sebesar Rp. 272,91/jam.

\section{Daftar Pustaka}

Adam, M., Sardino, S., Winaldi, D., Candra, S., Yunika, F., Riko, R., Novita, S., Herdian, F., Hendra, H., \& Laksmana, I. (2020). Rancang Bangun dan Analisis Alat Pencuci Wortel Tipe Drum. Lumbung, 19(1), 13-29. https://doi.org/10.32530/lumbung.v19i1.199

Haryoto. (1995). Pengupas Kacang Tanah. Yogyakarta, Indonesia: Penerbit Kanisius

Irwan A., \& Novita. S.A. (2016). Buku Kerja Praktek Mahasiswa (BKPM) Ekonomi Teknik. Politeknik Pertanian Negeri Payakumbuh. Payakumbuh, Indonesia: PPNP

Kodoatie, R. J. (2005). Analisis Ekonomi Teknik. Yogyakarta, Indonesia: Andi Yogyakarta.

Najiyanti, S., \& Danarti, (1999). Palawijaya: Budidaya dan Analisis Usahatani. Jakarta, Indonesia: Penebar Swadaya.

Novita, S., Hendra, H., Jamaluddin, J., Makky, M., \& Fahmi, K. (2019). Design and Performance Test of Rubber Grinding Machine. Journal of Applied Agricultural Science and Technology, 3(2), 299-308. https://doi.org/10.32530/jaast.v3i2.112

Salahudin, X., Widodo, S., \& Aslam, N. W. (2018). Uji Performa Mesin Pengupas Kulit Kacang Tanah Tipe Piramida Berputar. Prosiding Seminar Nasional Sains dan Teknologi ke 9 Fakultas Teknik, Universitas Wahid Hasyim Semarang.

Salahudin, X., \& Widodo, S. (2018). Pengaruh Jarak Ruji Mesin Pengupas Kacang Tanah Terhadap Kualitas Hasil Kupasan. Journal of Mechanical Engineering, 2(2), 1-7. http://dx.doi.org/10.31002/jom.v2i2.1087

Tahapali, R., Djafar, R., \& Djamalu, Y. (2019). Modifikasi Mesin Pengupas Kulit Kacang Tanah. $\begin{array}{llll}\text { Jurnal Teknologi Pertanian Gorontalo (JTPG), } & 4(2), \quad 78-82 .\end{array}$ https://doi.org/10.30869/jtpg.v4i2.466

Womsiwor, O., Nurmaini, N., Zikri, A., Hendra, H., Amrizal, A., Yudistira, Y., \& Batubara, F. (2018). Rancang Bangun Mesin Pengupas Dan Pencuci Singkong Tipe Horizontal. Journal of Applied Agricultural Science and Technology, 2(2), 11-19. https://doi.org/10.32530/jaast.v2i2.40

Zuhdi, M. H. (2015). Pengoptimalan Mesin Pengupas Kacang Tanah Untuk Meningkatkan Produktivitas. Magelang, Indonesia: Universitas Tidar. 